\title{
A gőzfázisú újraömlesztéses forrasztás megfigyelése újszerü alkalmazott szenzorikai módszerekkel
}

\author{
Géczy Attila ${ }^{1)}$, Mohamed Amine Alaya ${ }^{1)}$, Straubinger Dániel ${ }^{1)}$, \\ Hantos Gusztáv ${ }^{2)}$, Bozsóki István ${ }^{1)}$ \\ 1) Budapesti Müszaki és Gazdaságtudományi Egyetem \\ Elektronikai Technológia Tanszék, 1111 Budapest, Egry József u. 18. \\ ${ }^{2)}$ Budapesti Műszaki és Gazdaságtudományi Egyetem \\ Elektronikus Eszközök Tanszéke, 1117 Budapest, Magyar tudósok körútja 2. \\ E-mail: gattila@ett.bme.hu
}

Tartalmi kivonat. A gözfázisú forrasztás egy feltörekvö újraömlesztéses forrasztási módszer, amely elterjedése az ipari tömeggyártásban lassú ütemben zajlik, de speciális szakterületeken, és alkalmazásoknál már most kiemelt fontosságú megoldásként tekintenek rá. A kondenzációs höátadáson alapuló módszert egyenletes melegitése, többféle folyamatvezérlési lehetösége és a kiváló forrasztási minősége miatt alkalmazzák. A kondenzációhoz szükséges göztér beállitása (a rendszer vezérlése) és vizsgálata azonban több szempontból is kihívást jelent, így az alkalmazott szenzorikai megközelítésben újszerü megoldásokat kell keresni. A most bemutatott összefoglaló cikk rávilágít a folyamat jellegzetességeire, a vezérlési módokra, és bemutatja az újszerü alkalmazott szenzorikai (hömérsékletmérési, kapacitív, infrakamerás, nyomásmérési) módszereket, amelyek végül a folyamat szabályzásában, és végül az optimalizált forrasztási minöségben hasznosulhatnak.

Kulcsszavak: gözfázisú forrasztás, kondenzációs höátadás, alkalmazott szenzorika

\section{BEVEZETÉS}

Az elektronikai ipar szereléstechnológiája során kulcsfontosságú lépés az újraömlesztéses forrasztás. A szereléshez előkészített hordozóra (nyomtatott huzalozású lemez, áramköri hordozó, „printed circuit board" - PCB) stencilnyomtatással kerül fel a forrasz paszta formájában, majd automatizált alkatrészbeültetést követően hőközlést alkalmaznak a szerelvényen. Ez az újraömlesztés, amelynek a végén a visszahült forraszanyag létrehozza hordozó és alkatrész között a mechanikai-villamos kötést.

A hőátadási módszerek között elterjedt az infrasugárzáson alapuló hőátadás, az iparban számottevően a kényszerkonvekciós kemencéket használják [1], az elmúlt időszakban feltörekvő módszerként jelent meg a gőzfázisú forrasztás (,vapour phase soldering" - VPS) is [2], amely a filmszerü kondenzáció elvén alapul. A módszert 1975-ben fejlesztették ki [3], de az alkalmazott CFC-tartalmú hőközlő anyagok miatt háttérbe szorult a technológia, ami az elmúlt két évtizedben [4] és az ólommentes technológiák térnyerésével kezd ismét az ipari alkalmazás figyelmébe kerülni. Az új népszerüség oka a Galden folyadék széles körü elterjedése volt [5], amely perfluor-poliéter típusú, inert hőközlő anyagot kínált a hőátadáshoz.
A folyamat során a Galdent forralják egy tartály alján, a keletkező gőz pedig a kondenzációs hőátadás közegének tekinthető. A forrásponthoz képest hideg állapotban bemártott szerelvényen megindul a lecsapódás, ezzel pedig a filmszerü kondenzáció egyenletes hőátadási elvei érvényesülnek a szerelvény szabad felületein.

A módszert többféleképpen lehet alkalmazni. A standard megoldás (1. ábra. a) során telített gőzbe mártják a szerelvényt, amely rapid, de egyenletes felmelegedéssel áll be a csúcshőmérsékletre. Ettől egy fokkal összetettebb az úgy nevezett ,heat-level” módszer (b), ahol a szerelvényt egy fix pontra helyezik a kemencében, a Galden gőze pedig alulról tör a lemez irányába, ami a kondenzáció során folyamatosan elvonja maga körül a gőzt. Idővel (a fütési teljesítmény függvényében) a gőz túlfejlődik a lemezen vertikális irányban, amit egy szenzor jelez (jellemzően K-típusú hőelem). A harmadik lehetőség a telítetlen gőztakaróban való vertikális mozgatás, az úgynevezett „soft-VPS” (c) [6], ami komplex hőprofilok létrehozására lett kifejlesztve.

A fenti módszereket az 1. ábra mutatja be. A vezérlési módokat a későbbiekben további lehetőségekkel bővítették: a kemence munkatere kaphatott infra-előfútő zónát [6], kétrétegü 
gőzoszlopot, a zóna mentén vertikálisan elhelyezett többkörös hütőrendszert, és vákuumos kamrát, ahol az olvadt állapotban lévő forraszból vákuummal lehet a gázzárványok mennyiségét csökkenteni. [7]

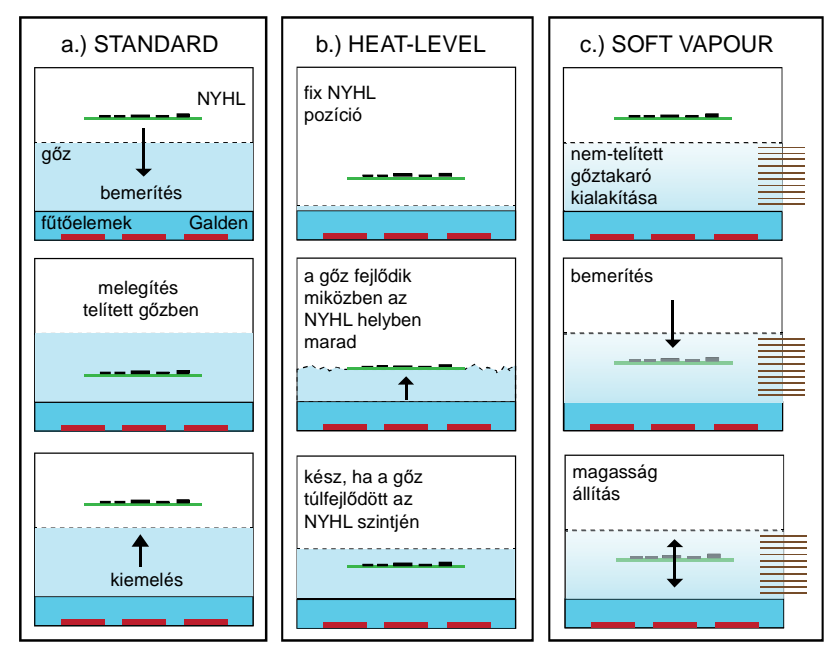

1. ábra. Különböző módszerek a hőátadásra gőzfázisú forrasztás során

\section{A FOLYAMAT MEGFIGYELÉSE HŐMÉRSÉKLETMÉRŐ SZENZOROKKAL}

A gőzfázisú forrasztóállomások belső megfigyelése általában hőelemekkel történik. Ezek közül leggyakoribb a K-típusú hőelem, amely szonda formájában, vagy a szerelvény vizsgálatára különböző rögzítési lehetőségekkel alkalmazható. A hőelemet a folyadékban, a gőztér különböző pontjaiban, a szerelvényen különböző pozíciókban, illetve a mintatartón szokás elhelyezni konstrukciótól függően.

A munkatérben és a szerelvényen elhelyezett hőelemek segítségével a munkatér hőmérséklete a $Z$ tengely mentén feltérképezhető, a hőmérsékletvisszacsatolás segítségével pedig előre leprogramozott profilkövetés valósítható meg. Géczy [8] és Livovsky [9] a visszacsatolt hőmérsékletet a fentebb bemutatott soft-VPS további finomítására használta. A hőelemek segítségével készített szabályzórendszer így elöre letárolt profilok lekövetésére [8], vagy egy forrasztási hőmérséklet-ablakban definiált profil megvalósítására [9] lehet alkalmas.

Livovsky tovább is fejlesztette a hőelemeken alapuló mérését [10] - ehhez egy "intelligens hőmenedzsment" rendszert fejlesztett ki, ami egy XMC4500 CPU-n alapul és egy LabView vezérelt PID szabályzót is tartalmaz, ami $\pm 2{ }^{\circ} \mathrm{C}$ hibával képes követni a programozott hőprofilt. Ezzel a rendszerrel a minta magasságát, a mozgatás sebességét, a minta méretét és a Galden folyadék szintjét is képes vizsgálni. A módszert sikeresen alkalmazták nagy hőkapacitású, kerámia alapú modulok esetében.

A hőelemeket (vagy adott esetben platina ellenállás hőmérőket) sikeresen alkalmaztuk létrás elrendezésben a gőztér magasságának feltérképezésére, kilencpontos 2D rács elrendezésben laterális hőmérséklet eloszlás és izoterma vizsgálatára (2. ábra). A mérési eredményekkel pedig telítési küszöböt (a kamra készenléti állapotát), illetve a gőztér kialakulásának fütési teljesítménytől való függését, és a szerelvények melegedésének folyamatát (felületen, vagy furatokba SMD ragasztóval rögzítve) is vizsgáltuk [11].

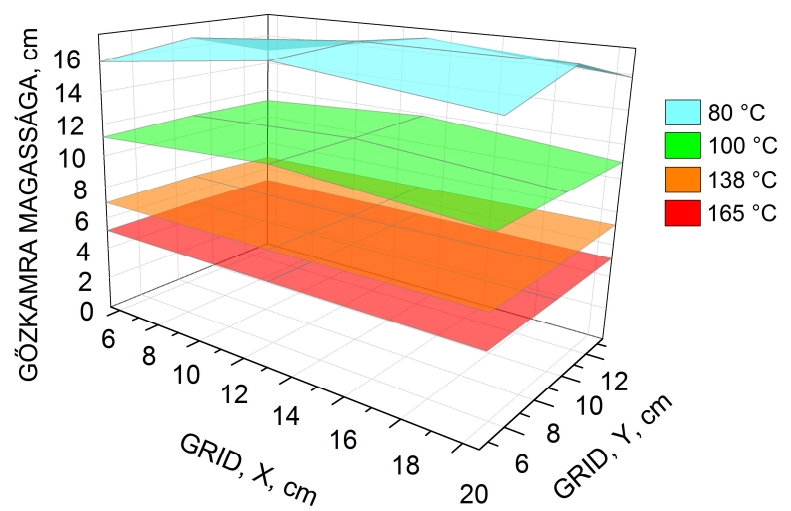

2. ábra. Izotermák vizsgálata $2 \mathrm{D}$ hőelemrács segítségével [11]

\section{A FOLYAMAT MEGFIGYELÉSE INFRAKAMERÁVAL}

A hőmérsékletet további lépésként infrakamerás mérőberendezéssel is vizsgáltuk, sajnos azonban a gőztér és a kemence falának nagymértékben eltérő emisszivitásának, valamint a gőztér árnyékolásának köszönhetően nem lehet konzekvens kvantitatív vizsgálatokat készíteni.

A módszerrel kvantitatívan verifikálni lehet a gőztakaró csúcshőmérsékletét, kvalitatívan a gőz kezdeti összeesése is megfigyelhető bemerítéskor, a kamera a kemence rosszul hőszigetelt pontjainak feltérképezésére is alkalmas. A 3. ábra egy kísérleti forrasztóállomás nyitott zsilipét mutatja, ahol a bemerített szerelvény nem látszik, a gőztakaró maximális hőmérséklete azonban leolvasható a felvételről. A mérés során a kamera a gőztakaró hőmérsékletéhez lett kalibrálva. 


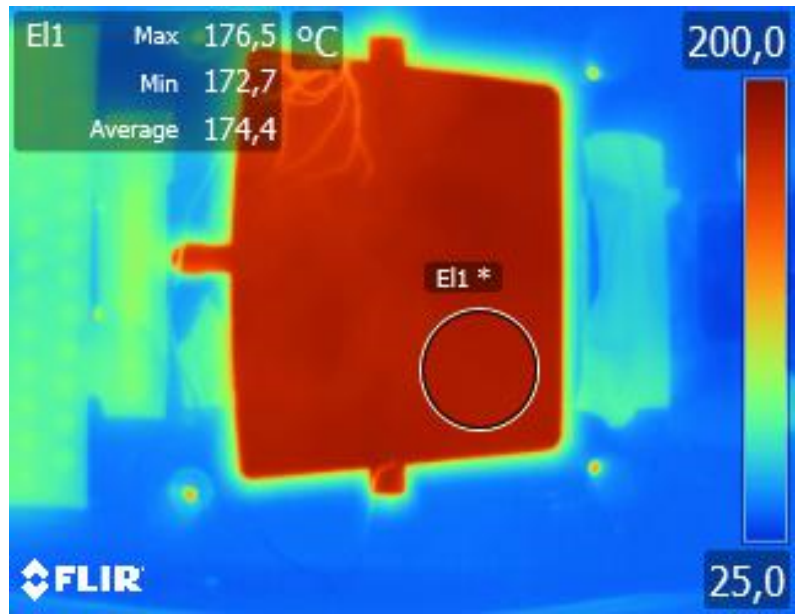

3. ábra. Infrakamerás felvétel a bemerített szerelvényről

\section{A FOLYAMAT MEGFIGYELÉSE KAPACITÍV SZENZOROKKAL}

Livovsky a magasság megfigyelését később egy kapacitív szenzorral bővítette ki, amely saját fejlesztésű egységből állt. Ez párhuzamos kerámialapok közé helyezett rézlapokból készült, amit a 4. ábra is mutat. A vertikálisan elhelyezett rézlapok közé törő gőz és folyadék dielektromos állandójának változásából lehet következtetni a telített gőz magasságára.

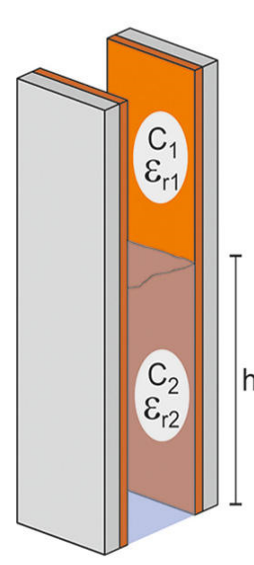

(a)

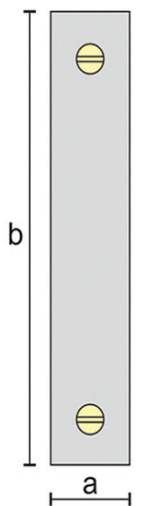

d ${ }_{H}$

(b)

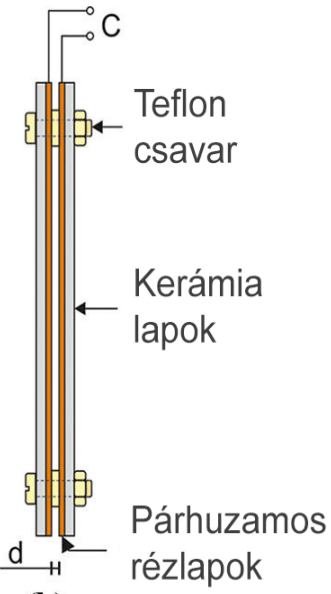

rézlapok
4. ábra. Kapacitív elven működő magasságérzékelő: a) kétféle anyag a fegyverzetek között; b) a konstrukció [12]

Amennyiben a szenzort a folyadékba is bemerítik, úgy a Galden hőtágulását is vizsgálni lehet, amivel a forró folyadék felső szintjének pontos megfigyelése válik lehetővé. [12]

\section{A FOLYAMAT MEGFIGYELÉSE NYOMÁSMÉRŐ SZENZOROKKAL}

A nyomásmérő szenzorokra a hőmérsékletmérés időbeli bizonytalansága miatt lehet szükség. Különböző nyomásmérőkkel megállapítható a gőztér változása (szaturált gőztakaró növekedése) lekövethetővé válik a készenléti állapot kialakulása, a folyadék felszínére merőlegesen, attól kis távolságra $(\mathrm{pl} .1 \mathrm{~cm})$ elhelyezett szondával. [11] A következő, 5. ábra bemutatja a mérési elrendezést.

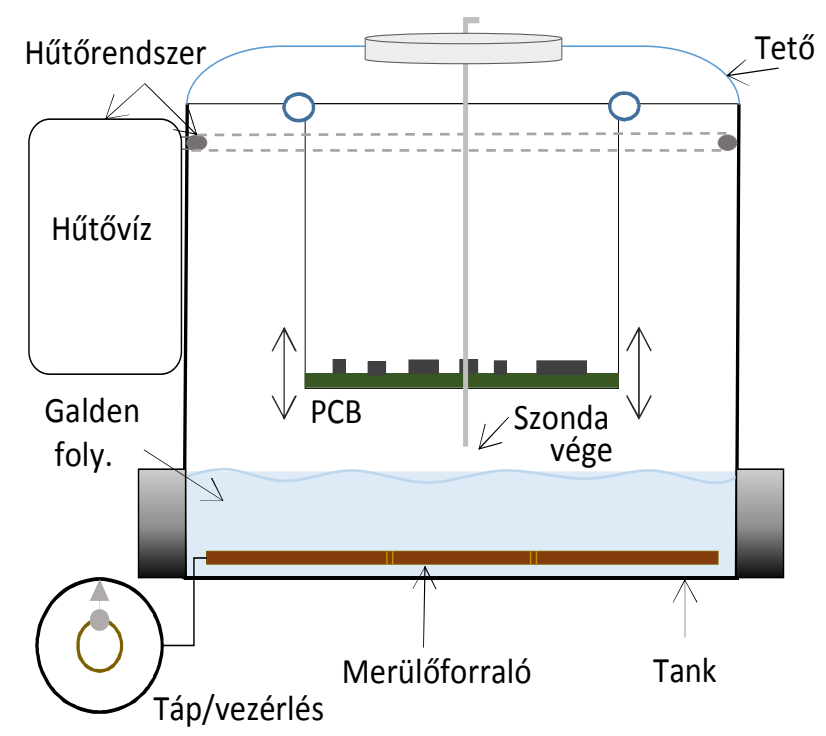

5. ábra. Nyomásmérő szenzor szondájának elhelyezése a gőztérben

A módszert eleinte hőmérő szenzor és dinamikus átfolyásmérő szenzor fúziójával fejlesztettük ki, ez a közelmúltban egészült ki az újszerü, membrános „gage”-típusú nyomásmérő szenzorok alkalmazásával, amelyek a többletnyomás jelzésére alkalmasak. Ezek segítségével megállapítható, hogy amikor a gőztakaró hőmérséklete már nagyon kis meredekséggel közelíti a csúcshőmérsékletet, a maximális telítődés még nincs kialakulva. A dinamikus átfolyásmérővel (Sensirion SDP alkatrész) korábban is megfigyeltük, hogy a dinamikus csúcs precízebben definiálja a telítődést, most az új típusú szenzorokkal kimondható, hogy a tényleges telítődés (a hidrosztatikai nyomás maximuma) a dinamikus viselkedés visszaesésével valósul meg. A módszer további érdeme, hogy a korábbiaknál pontosabban jelezhető vele jelcsúcs formájában a készenléti állapot, így jelenleg szabályzás szempontjából ez tekinthető a leggyorsabb, legpontosabb telített gőztakaró kialakulását jelző megoldásnak. A módszerrel a teljesítmény/felfütési idő függvények is felderíthetőek, a stabil gőztakaróhoz szükséges minimum teljesítmény meghatározásával. A hidrosztatikai nyomásmérés elvével a telített gőztakaró magassága nagy pontossággal $(\sim \mathrm{mm}$ nagyságrendben) mérhető. 


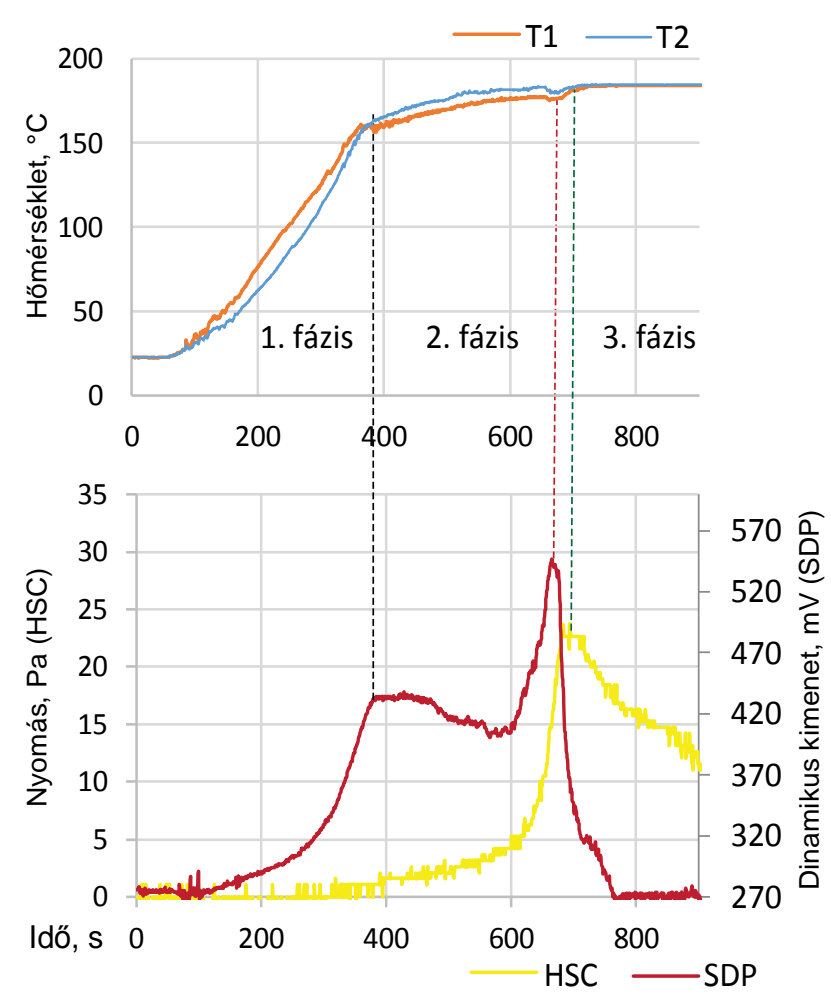

6. ábra. Nyomásmérő szenzor és hőelem fúziója jelzi a telített gőztakaró kifejlődését (3. fázis)

\section{6. ÖSSZEFOGLALÁS}

A cikkben bemutatásra kerültek a gőzfázisú forrasztás vezérlési módszerei. Emellett bemutatásra kerültek a hőmérsékleti szenzoros, az infrakamerás, a kapacitív- és a nyomásmérők alkalmazásával történő folyamatmegfigyelési módszerek. Megállapítható, hogy a gyors ütemben fejlődő szenzorika adott határok között, de komoly lehetőségeket hordoz magában, a komplex kondenzációs folyamathoz alkalmazott kemencék állapotának megfigyeléséhez. A jövőbeli munka a nyomásmérés lehetőségeinek kiterjesztésére, valamint a kondenzáció vizsgálatának újszerü szenzoros megoldásaira (úgymint Peltier elem és tömegmérő szenzorok használatára) irányul.

\section{KöSZÖNETNYILVÁNíTÁS}

F A kutatást a Bolyai János Kutatási Ösztöndíj támogatta. A cikk az emberi erőforrások minisztériuma ÚNKP-18-4 kód-számú új nemzeti kiválóság programjának támogatásával készült.

\section{IRODALOMJEGYZÉK}

[1] Lee N.C., „Reflow soldering processes andtroubleshooting: sMT, BGA, CSP and flip chip technologies", BH Newnes kiadó, Boston, 2002.

[2] Sprovieri J., „Getting the vapors”, Assembly Magazine, 2002. Február.

[3] Pfahl R.C., Ammann H.H., „Method for Soldering, Fusing or Bracing", US Patent 3,866,307, 1975.

[4] Leider W., ,Dampfphasenlöten - Grundlagen Und Praktische Anwendung”, E.G. Leuze Verlag kiadó, Bad Saulgau, 31-39 o., 2002.

[5] Leicht H., Thumm A., ,Today's vapor phase soldering - an optimized reflow technology for lead free soldering", SMTA conf., Orlando, 2008.

[6] Lipp J., Thumm A., ,High Quality Vapor Phase Reflow Soldering, The Advanced Soft Soldering Technology", SMTA Arizona conf., 2012.

[7] Synkiewicz B.K., Skwarek A., Witek K., ,,Voids investigation in solder joints performed with vapour phase soldering (VPS)", Solder. Surf. Mt. Tech., 26. évfolyam, 1. szám, 8-11 o., 2013. DOI: 10.1108/SSMT-10-2013-0028

[8] Géczy A., Kiss B.P., Alaya A.M., Illyefalvi-Vitéz Z., „Refined Approach on Controlling Heat Transfer in a Vapour Phase Soldering Oven", 42nd ISSE conf., Poland, 2019. (közlésre elfogadva).

[9] Livovsky L., Pietrikova A., Durisin J., ,Monitoring of the temperature profile of vapour phase reflow soldering", 31st ISSE conf., 667-669. o., 2008. DOI: 10.1109/ISSE.2008.5276585

[10] Livovsky L., Pietrikova A., ,,Real-time profiling of reflow process in VPS chamber", Solder. Surf. Mt. Tech., 29. évfolyam, 1. szám, 42-48. o., 2017. DOI: $10.1108 /$ SSMT-10-2016-0026

[11] Géczy A., ,Investigations into the process of vapour phase soldering, A gőzfázisú forrasztási technológia folyamatának vizsgálata", PhD Disszertáció; $B M E$, 2014.

[12] Livovsky L., Pietrikova A., „Measurement and regulation of saturated vapour height level in VPS chamber", Solder. Surf. Mt. Tech., (közlésre elfogadva), 2019.

DOI: 10.1108/SSMT-10-2018-0040 